\title{
FIRST AID MANAGEMENT IN EMERGENCY CARE OF DENTAL INJURIES - KNOWLEDGE AMONG TEACHERS IN RIJEKA, CROATIA
}

\author{
Danko Bakarčić ${ }^{1}$, Sandra Hrvatin ${ }^{1}$, Mia Maroević ${ }^{2}$ and Nataša Ivančić Jokić ${ }^{1}$ \\ ${ }^{1}$ School of Medicine, Department of Pediatric Dentistry, University of Rijeka, \\ Rijeka University Hospital Center, Rijeka; ${ }^{2}$ Smile Dental Clinic - Private Practice, Opatija, Croatia
}

SUMMARY - The aim of the present cross-sectional study was to investigate the knowledge and attitude regarding emergency treatment of dental trauma among elementary school teachers in the city of Rijeka, Croatia. A total of 144 teachers answered a four-part questionnaire which comprised questions regarding demographic data, role and responsibility at the working place, knowledge about dental trauma, and motivation for further education on the topic. Nearly half of the participants (47.2\%) reported having seen at least one dental trauma in their professional careers. They chose to contact the child's parent first (54.1\%) and only $11.1 \%$ chose to contact a dentist instead. The majority of teachers (81.9\%) were not aware of the meaning of the term avulsio dentis. As to treatment of avulsed tooth, $17.3 \%$ of teachers knew the appropriate management, while $14 \%$ of them would not even touch it. With regard to transport of avulsed tooth or fractured tooth fragments, only $2 \%$ responded correctly. The majority of the responders $(87.5 \%)$ had never been educated about dental trauma, but were willing to be informed through lectures (53.4\%), basic life support courses (15.2\%) and brochures (9.7\%). Planning teachers' education through advanced training on the topic is suggested to be part of teachers' lifetime education.

Key words: Tooth injuries; Tooth avulsion; Schools; Child; Adolescent; Young adult; Health knowledge, attitudes, practice; Teaching; Emergency treatment - psychology; Croatia

\section{Introduction}

Dental injuries have become an oral health issue due to their high prevalence and complex approach that may be required with respect to emergency management of traumatized teeth ${ }^{1,2}$.

Dental trauma can occur at any age; however, a significantly high incidence of traumatized permanent teeth has been reported between the age of 7 and $12^{1,3}$. The majority of children and young adults visiting the University Dental Clinic in Rijeka, Croatia due to dental trauma are aged 10 to 13 years, followed by children aged 6 to 9 years ${ }^{4,5}$. A study conducted at the

Correspondence to: Sandra Hrvatin, DMD, Krešimirova 40, HR51000 Rijeka, Croatia

E-mail: san_hrvatin@yahoo.com

Received September 17, 2015, accepted July 7, 2016
University Dental Clinic in Zagreb, Croatia showed the highest frequency of dental trauma in permanent dentition at the age of nine ${ }^{6}$. Most dental injuries occur during day time between $11.00 \mathrm{am}$ and $1.00 \mathrm{pm}$, as well as between $4.00 \mathrm{pm}$ and $8.00 \mathrm{pm}$, when most of the children are at school supervised by their teach$\mathrm{ers}^{7,8}$. Since the prognosis of traumatized teeth depends highly on immediate and appropriate management of the teeth, teachers who witness such a trauma are expected to provide prompt and proper sequence of actions in order to minimize or possibly exclude certain functional, esthetic, psychological and economic side effects for the patient ${ }^{9,10}$. In the past years, many studies have shown the teachers' knowledge regarding management of dental injuries to be quite poor and inadequate ${ }^{11-16}$. No data are available to access elementary school teachers' knowledge about managing den- 
tal injuries in Croatia. Therefore, the aim of this study was to investigate potential improvement of the teachers' knowledge related to the topic by accessing data from elementary schools in the city of Rijeka, Croatia. The aim was also to evaluate their attitudes to emergency management of dental injuries, to further evaluate the procedures that were undertaken among those who had had such experience, and to investigate to which extent they were motivated for further education on the matter. The results of this report could provide information that can assist in creating simple instructive guidelines for teachers as part of the following long-term educative approach in their training. The final goal is to reduce the possible complications associated with dental trauma among schoolchildren and adolescents at an early stage.

\section{Materials and Methods}

This cross-sectional study was carried out in 14 elementary schools in Rijeka, the third biggest city in Croatia. Prior to commencing the study, it was approved by the Ethics Committee of the School of Medicine, University of Rijeka, Croatia. Data were collected by distributing a questionnaire that comprised 25 questions divided in 4 parts. The first part consisted of 4 questions regarding personal information, including age, gender, level of graduation, number and age of their own children. The second part consisted of 6 questions referring to teachers' role in the school and their responsibilities and obligations in school activities. The third part consisted of 6 questions focused on teachers' knowledge and previous experience with dental injuries. Finally, the fourth part consisted of 6 questions evaluating their self-assessed education and motivation with respect to gaining additional knowledge about dental injuries.

The questionnaire was developed by the authors of the study as part of the graduate thesis at the University of Rijeka, School of Medicine, Department of Pediatric Dentistry. All the participants initially approached gave their consent to participate in the study. To ensure the participants' self-approach in answering the questions and exclude any side intervention and consultation in the course of filling out the questionnaire forms, the investigators were individually present in schools to distribute the surveys and stayed there until the teachers completed the questionnaires. To ensure anonymity, no names, other personal information or names of the schools were recorded. All of the 148 questionnaires were distributed during a 2-month period, starting from January 2014 through March 2014. A total of 144 questionnaires were properly filled out, whereas 4 questionnaires were excluded due to incomplete answers. Three of the authors reviewed the questionnaires and no disagreement was reported among them.

Descriptive statistical analysis was performed by using STATISTICA for Windows Release 5.5 A* and SPSS for Windows, Release 7.5**.

\section{Results}

The questionnaire was completed correctly by 144 of $148(97.3 \%)$ teachers, their age range 25-62 years, mean age 41 ( $\mathrm{SD} \pm 9.39)$ years. The study included mostly female teachers (94.5\%) and only four (5.5\%) males. The majority of teachers had their own children (81.1\%); $53.3 \%$ had one child, $45 \%$ had two children, and $1.7 \%$ had three children.

The average teaching experience was 10 years. The majority of teachers included in the study (87.8\%) approved supervising children during sports activities, while $94.6 \%$ of them were doing that even in recess

Table 1. Knowledge and experience with dental injuries $(N=144)$

\begin{tabular}{|c|c|c|}
\hline Question & Answer & $\mathrm{n}(\%)$ \\
\hline $\begin{array}{l}\text { Experience } \\
\text { with dental } \\
\text { injuries }\end{array}$ & $\begin{array}{l}\text { Yes } \\
\text { No }\end{array}$ & $\begin{array}{l}38(26.38) \\
106(73.61)\end{array}$ \\
\hline $\begin{array}{l}\text { Witnessing } \\
\text { dental injuries }\end{array}$ & $\begin{array}{l}\text { Yes, once } \\
\text { Yes, several times } \\
\text { No }\end{array}$ & $\begin{array}{l}14(9.72) \\
54(37.5) \\
76(52.78) \\
\end{array}$ \\
\hline $\begin{array}{l}\text { How did dental } \\
\text { injuries occur }\end{array}$ & $\begin{array}{l}\text { Sports activities } \\
\text { Walking } \\
\text { Playing } \\
\text { Physical contact } \\
\text { Other situation } \\
\end{array}$ & $\begin{array}{l}18(12.5) \\
16(11.11) \\
90(62.5) \\
4(2.7) \\
16(11.11)\end{array}$ \\
\hline $\begin{array}{l}\text { What would } \\
\text { you do in case } \\
\text { of dental } \\
\text { injuries }\end{array}$ & $\begin{array}{l}\text { Contact the child's } \\
\text { parents } \\
\text { Contact the dentist } \\
\text { Contact the } \\
\text { headmaster } \\
\text { Hold the child at } \\
\text { school }\end{array}$ & $\begin{array}{l}78(54.16) \\
16(11.11) \\
38(26.38) \\
12(8.33)\end{array}$ \\
\hline
\end{tabular}


Table 2. Management of dental injuries $(N=144)$

\begin{tabular}{|c|c|c|}
\hline Question & Answer & n (\%) \\
\hline $\begin{array}{l}\text { Familiarity } \\
\text { with the term } \\
\text { of avulsio dentis }\end{array}$ & $\begin{array}{l}\text { Yes } \\
\text { No }\end{array}$ & $\begin{array}{l}26(18.05) \\
118(81.94)\end{array}$ \\
\hline $\begin{array}{l}\text { What would } \\
\text { you do in case } \\
\text { of a completely } \\
\text { extruded tooth } \\
\text { from its socket }\end{array}$ & $\begin{array}{l}\text { Throw the tooth away } \\
\text { Scrub the tooth } \\
\text { Wash the tooth } \\
\text { with tap water } \\
\text { Wrap the tooth } \\
\text { in a dry clean gauze } \\
\text { or handkerchief } \\
\text { Place the tooth in milk } \\
\text { Place the tooth in } \\
\text { physiological solution } \\
\text { Place the tooth in } \\
\text { disinfectant solution }\end{array}$ & $\begin{array}{l}3(2.08) \\
9(6.25) \\
3(2.08) \\
\\
110(76.38) \\
3(2.08) \\
5(3.47) \\
11(7.63) \\
\end{array}$ \\
\hline $\begin{array}{l}\text { How would } \\
\text { you hold a } \\
\text { completely } \\
\text { extruded tooth }\end{array}$ & $\begin{array}{l}\text { By the crown } \\
\text { By the root } \\
\text { By the whole tooth } \\
\text { Would not touch it }\end{array}$ & $\begin{array}{l}25(17.36) \\
38(26.38) \\
60(41.6) \\
21(14.6)\end{array}$ \\
\hline $\begin{array}{l}\text { Would you look } \\
\text { after a missing } \\
\text { tooth fragment }\end{array}$ & $\begin{array}{l}\text { Yes } \\
\text { No }\end{array}$ & $\begin{array}{l}39(27.08) \\
105(72.9)\end{array}$ \\
\hline $\begin{array}{l}\text { Do you think } \\
\text { that a fractured } \\
\text { fragment } \\
\text { could be } \\
\text { reattached to } \\
\text { the traumatized } \\
\text { tooth }\end{array}$ & $\begin{array}{l}\text { Yes } \\
\text { No }\end{array}$ & $\begin{array}{l}26(18) \\
118(82)\end{array}$ \\
\hline
\end{tabular}

time. Teachers were responsible for one classroom at a time with the mean number of 20 pupils ( $\mathrm{SD} \pm 4.56$ ).

Table 1 shows the responders' knowledge about and experience with dental injuries. Nearly one-third of the responding teachers (26.38\%) reported having self-experience with dental trauma and nearly half of them $(47.22 \%)$ reported having seen at least one trauma during their teaching careers, mostly during children's play (62.5\%). Only $11.11 \%$ of the responding teachers approved contacting a dentist first after having witnessed the accident, while the majority (54.16\%) would call the child's parents instead.

Table 2 shows the teachers' knowledge about emergency measures with injured teeth. The majority of the responding teachers $(81.94 \%)$ were not aware of the meaning of the term avulsio dentis. When presented
Table 3. Education about dental injuries ( $N=144)$

\begin{tabular}{|c|c|c|}
\hline Question & Answer & n (\%) \\
\hline $\begin{array}{l}\text { Have you ever } \\
\text { been educated } \\
\text { about dental } \\
\text { injuries }\end{array}$ & $\begin{array}{l}\text { Yes } \\
\text { No }\end{array}$ & $\begin{array}{l}9(6.25) \\
135(93.75)\end{array}$ \\
\hline $\begin{array}{l}\text { In which way } \\
\text { you got } \\
\text { informed } \\
\text { about dental } \\
\text { injuries }\end{array}$ & $\begin{array}{l}\text { Consulting an expert } \\
\text { Consulting colleagues } \\
\text { Dental literature } \\
\text { Lectures } \\
\text { Specialized TV/ radio } \\
\text { shows } \\
\text { Online education } \\
\text { Newspapers } \\
\text { Didn't need such } \\
\text { information } \\
\text { Not interested }\end{array}$ & $\begin{array}{l}28(19.45) \\
46(32) \\
14(9.72) \\
1(0.7) \\
\\
4(9.72) \\
6(4.16) \\
1(0.7) \\
\\
28(19.4) \\
6(4.16)\end{array}$ \\
\hline $\begin{array}{l}\text { Are you } \\
\text { interested } \\
\text { in being } \\
\text { educated about } \\
\text { dental injuries }\end{array}$ & $\begin{array}{l}\text { Yes } \\
\text { No }\end{array}$ & \begin{tabular}{|l}
$126(87.5)$ \\
$18(12.5)$
\end{tabular} \\
\hline $\begin{array}{l}\text { The best way to } \\
\text { be educated } \\
\text { about dental } \\
\text { injuries }\end{array}$ & $\begin{array}{l}\text { Basic life support } \\
\text { courses } \\
\text { Seminars } \\
\text { Lectures by dentists } \\
\text { at school } \\
\text { Brochures } \\
\text { Online education } \\
\text { Not interested }\end{array}$ & $\begin{array}{l}22(15.2) \\
7(4.86) \\
\\
77(53.4) \\
14(9.72) \\
10(7) \\
14(9.72)\end{array}$ \\
\hline
\end{tabular}

with a scenario in which they find an avulsed tooth or a tooth fragment, $14.6 \%$ of the teachers would not touch it. Only $17.36 \%$ of them would hold a completely extruded tooth for the crown and $2 \%$ knew that an avulsed tooth should be transported to a dental office in milk. The majority (76.38\%) would wrap it in clean and dry gauze.

Table 3 shows the responders' self-assessed knowledge and motivation for education. The majority (93.75\%) reported they had never been educated about dental injuries, $58.1 \%$ found their knowledge on dental injuries be insufficient, whereas the majority (87.7\%) thought that further education on the subject was required. As to the manner of gaining additional knowledge, the majority would prefer lectures in schools (53.4\%), courses of basic life support (15.2\%) and brochures (9.2\%). 


\section{Table 4. Protocol for emergency management of dental trauma}

All dental traumas should be treated as emergencies. So please, when you witness a facial trauma:

1) ask the child to show you his/her teeth; 2) contact the child's parents; 3) visit a dentist as soon as possible

1. All teeth are present

\begin{tabular}{|l|l|}
\hline Clinical finding & Management \\
\hline $\begin{array}{l}\text { No Displacement of the tooth with/without bleeding } \\
\text { around the tooth - normal biting }\end{array}$ & $\begin{array}{l}\text { Contact the child's parents and visit a dentist as soon } \\
\text { as possible }\end{array}$ \\
\hline $\begin{array}{l}\text { The tooth is loosened or pushed out of position } \\
\text { with bleeding around the tooth - unable to bite }\end{array}$ & $\begin{array}{l}\text { Try to replace the tooth gently in the right position } \\
\text { and visit a dentist as soon as possible }\end{array}$ \\
\hline
\end{tabular}

2. Chipped or broken tooth

\begin{tabular}{|l|l|}
\hline Clinical finding & Management \\
\hline Missing tooth crown fragment & Recover and store the missing fragment in cold milk until arrival to dental \\
& office \\
& It can be reattached! \\
& Visit a dentist as soon as possible \\
\cline { 2 - 2 } & Cannot find the missing fragment? \\
& Visit a dentist as soon as possible anyway \\
\hline
\end{tabular}

\section{Missing tooth}

\begin{tabular}{|c|c|}
\hline Clinical finding & Management \\
\hline $\begin{array}{l}\text { The tooth socket is empty: } \\
\text { it means that the tooth was } \\
\text { completely displaced from its socket }\end{array}$ & $\begin{array}{l}\text { A. REPLANTATION } \\
\text { Find the tooth and pick it up for the crown } \\
\text { Do not touch the root! } \\
\text { Rinse it with tap water for } 10 \mathrm{~s} \\
\text { Ask the child to rinse the mouth with water } \\
\text { Replace the tooth gently into the empty socket } \\
\text { Use the adjacent tooth for comparison of right position and rotation } \\
\text { Ask the child to bite on a handkerchief to hold the tooth in position } \\
\text { Seek emergency dental treatment immediately } \\
\text { B. NO REPLANTATION } \\
\text { If replantation is not possible place the tooth in appropriate storage medium: } \\
\text { - cold milk } \\
\text { - saliva } \\
\text { Best: special storage media for teeth } \\
\text { Avoid water } \\
\text { Never leave the tooth in a dry gauze or handkerchief }\end{array}$ \\
\hline $\begin{array}{l}\text { The tooth socket seems empty but } \\
\text { the tooth is displaced axially into the } \\
\text { bone and usually only part of the } \\
\text { tooth crown is visible (white) }\end{array}$ & Seek emergency dental treatment immediately \\
\hline
\end{tabular}

\section{Discussion}

Schools and schoolyards are one of the locations with the greatest prevalence of the occurrence of dental trauma in children ${ }^{1}$. Therefore, promoting awareness of emergency management modalities among teachers and other school staff is mandatory $\mathrm{y}^{1,17,18}$. Prompt and appropriate actions that can be undertaken immediately after dental injuries can increase survival rates of injured tooth, particularly in complicated cases such as avulsion. Immediate reaction to dental injury can also reduce the level of children's and their 
parents' anxiety with respect to subsequent dental treatment ${ }^{19}$. In the last decades, many studies evaluated the knowledge of dentists, teachers, primary care providers, coaches and other lay people regarding emergency dental trauma measures ${ }^{20-23}$. The results of this study are much in accordance with the existing data from similar studies conducted in Turkey, Czech Republic and Brazil enouncing the role of teachers in the provision of primary care following dentoalveolar injuries ${ }^{13,14,24}$. More specifically, the majority of the investigated teachers showed rather poor level of knowledge, stating they would contact the child's parents $(54.16 \%)$ after dental injury and hold the child at school until their parents' arrival (8.3\%). Contacting a dentist to manage the fractured tooth was considered by only $11.11 \%$ of the responders. Late and inappropriate interventions may complicate and prolong therapy of the injured tooth with unsuccessful long-term outcomes. In particular, permanent incisors with incomplete root development, which are known to be most affected by trauma, may suffer from the consequences of such inadequate treatment approach ${ }^{1,25,26}$. Consequently, prolonged therapy requires more dental appointments, which also affects school activities. In case of tooth avulsion, the time elapsed between the accident and the patient's arrival to dental office, as well as appropriate storage and transportation media are crucial for favorable prognosis of tooth survival in the jaw ${ }^{27}$. Conversely, incorrect handling of the avulsed tooth and prolonged extraoral dry time may result in damage to periodontal ligament, root inflammatory resorption or ankylosis, which can lead to tooth $\operatorname{loss}^{28}$. Immediate replantation after tooth complete extrusion from its socket was not considered because previous studies have shown teachers' aversion to this procedure ${ }^{29,30}$. As to manage a completely extruded tooth, the majority of teachers $(68 \%)$ would hold the tooth incorrectly and wrap it in a dry gauze (76.38\%), thus causing permanent damage to periodontal tissue. This finding is similar to those observed in studies conducted in other countries ${ }^{14,24}$. Only a lower percentage of teachers $(2.08 \%)$ would place the tooth in milk, which was available in all 14 schools included in this study. Milk can be used as a storage medium before tooth replantation because it can preserve vitality of the remaining cells on the root surface. Because of its neutral $\mathrm{pH}$, physiological osmolality, content of growth factors and essential nutrients for cells, and no bacterial con- tent, milk is recommended by the International Association of Dental Traumatology as a temporary storage medium for avulsed teeth ${ }^{31}$.

Fractured tooth fragment can be reattached to traumatized tooth by dentist in order to preserve tooth vitality and for esthetic reasons. When presented with a scenario of tooth crown fracture with loss of tooth substance, 105 (72.9\%) teachers would not look after the missing pieces and $82 \%$ thought that fragment reattachment to the tooth was not possible. Çaglar et al. report similar results in a study investigating teachers' awareness of proper management of traumatized teeth $^{13}$. Nearly $50 \%$ of the teachers witnessed at least one dental accident and the majority expressed interest in further education on the topic, preferring lectures given by dentists at school, basic life support courses, brochures or online learning. A written protocol with simple guidelines for emergency management of dental trauma could be useful and easily delivered in all elementary schools, as shown in Table 4.

Several studies though showed an increased level of knowledge about dental trauma among teachers who had attended education and suggested a combination of brochures and lectures as the best way to promote first aid procedures in case of dental injuries ${ }^{32,33}$.

This study had some limitations as participants' responses were self-reported and caution with generalization must be considered. However, the $97.3 \%$ response rate was excellent. For better results, it would be advisable to include in the study teachers from all elementary schools in Rijeka.

\section{Conclusion}

The knowledge about first aid management of dental injuries is poor and inadequate among elementary school teachers in the city of Rijeka, Croatia. Since they have shown interest in future education on the topic, training and educational programs are advisable to become part of their lifetime education.

\section{References}

1. Treabert J, Peres MA, Blank V, Böel RS, Pietruza JA. Prevalence of traumatic dental injury and associated factors among 12-year-old school children in Florianópolis, Brazil. Dent Traumatol. 2003;19:15-8, doi: 10.1034/j.1600-9657.2003.00138.x 
2. Glendor U. Epidemiology of traumatic dental injuries - a 12year review of the literature. Dent Traumatol. 2008;24:603-11, doi:10.1111/j.1600-9657.2008.00696.x

3. De Carvalho Rocha MJ, Cardoso M. Traumatized permanent teeth in Brazilian children assisted at the Federal University of Santa Caterina, Brazil. Dent Traumatol. 2001;17:245-9, doi:10.1034/j.1600-9657.2001.170601.x

4. Ivancic Jokic N, Bakarcic D, Fugosic V, Majstorovic M, Skrinjaric I. Dental trauma in children and young adults visiting a University Dental Clinic. Dental Traumatol. 2009;25:84-7, doi:10.1111/j.1600-9657.2008.00711.x

5. Ivančić Jokić N, Pavlić A, Bakarčić D. Premanent teeth dental trauma in children and young adults in Rijeka, Croatia. Stomatol Vjesn. 2012;2:129-33.

6. Vuletić M, Škaričić J, Soldo M, Trampuš Z, Čuković-Bagić I, Jurić $H$. Causes and prevalence of dental and oral soft tissue injuries in school children in Zagreb, Croatia. Paediatr Croat. 2014;58:171-5, http://dx.doi.org/10.13112/PC.2014.31

7. Goršeta K, Negovetić-Vranić D, Škrinjarić T, Glavina D. Traumatske ozljede mliječnih zuba: analiza oblika i uzroka. Acta Stomatol Croat. 2010;44:47-52. (in Croatian)

8. Škrinjarić I. Traume zuba u djece. Zagreb: Naklada Globus 1988. (in Croatian)

9. Ulusoy AT, Onder H, Cetin B, Kaya S. Knowledge of medical hospital emergency pshysicians about the first-aid management of traumatic tooth avulsion. Int J Paediatr Dent. 2012; 22:211-6, doi: 10.1111/j.1365-263X.2011.01178.x

10. Da Silva AC, Passeri LA, Mazzonetto R, De Moraes M, Moreira RWF. Incidence of dental trauma associated with facial trauma in Brazil: a 1-year evaluation. Dent Traumatol. 2004;20:6-11, doi:10.1111/j.1600-4469.2004.00212.x

11. Fux-Noy A, Sarnat H, Amir E. Knowledge of elementary school teachers in Tel-Aviv, Israel, regarding emergency care of dental injuries. Dental Traumatol. 2011;27:252-6, doi:10.1111/ j.1600-9657.2010.00970.x

12. Jorge KO, Ramos-Jorge ML, De Toledo FF, Alves LC, Paiva SM, Zarzar PM. Knowledge of teachers and students in physical education's faculties regarding first-aid measures for tooth avulsion and replantation. Dental Traumatol. 2009;25:494-9, doi:10.1111/j.1600-9657.2009.00823.x

13. Çaglar E, Ferreira LP, Kargul B. Dental trauma management knowledge among a group of teachers in two south European cities. Dental Traumatol. 2005;21:258-62, doi:10.1111/j.16009657.2005.00321.x

14. Tzigkounakis V, Merglova V. Attitude of Pilsen primary school teachers in dental trauma. Dental Traumatol. 2008;24:528-31, doi:10.1111/j.1600-9657.2008.00645.x

15. Blakytny C, Surbuts A, Thomas A, Hunter ML. Avulsed permanent incisors: knowledge and attitude of primary school teachers with regard to emergency management. Int J Paediatr Dent. 2001;11:327-32, doi:10.1046/j.0960-7439.2001.00288.x

16. Newman LJ, Crawford PJM. Dental injuries: "first aid" knowledge of Southampton teachers of physical education. Dent
Traumatol. 1991;7:255-8, doi:10.1111/j.1600-9657.1991.tb 00213.x

17. O’Neil DW, Clark MV, Lowe JW, Harrington MS. Oral trauma in children: a hospital survey. Oral Surg Oral Med Oral Pathol. 1989;68:691-6, http://dx.doi.org/10.1016/0030-4220 (89)90157-6

18. Al-Jundi SH. Dental emergencies presenting to a dental teaching hospital due to complications from traumatic dental injuries. Dent Traumatol. 2002;18:181-5, doi:10.1034/j.16009657.2002.02081.x

19. Levin L, Friedlander LD, Geiger SB. Dental and oral trauma and mouthguard use during sport activities in Israel. Dent Traumatol. 2003;19:237-42, doi:10.1034/j.1600-9657.2003. 00196.x

20. Holan G, Shmueli Y. Knowledge of physicians in hospital emergency rooms in Israel on their role in case of avulsion of permanent incisors. Int J Paediatr Dent. 2003;13:13-9, doi: 10.1046/j.1365-263X.2003.00414.x

21. Mori GG, Turcio KHL, Borro VPB, Mariusso AM. Evaluation of the knowledge of tooth avulsion of school professionals from Adamantina, Sao Paulo, Brazil. Dent Traumatol. 2007;23:2-5, doi:10.1111/j.1600-9657.2005.00391.x

22. Qazi SR, Nazir KS. First-aid knowledge about tooth avulsion among dentists, doctors and lay people. Dent Traumatol. 2009;25:295-9, doi:10.1111/j.1600-9657.2009.00782.x

23. Santos MESM, Habecost APZ, Gomes FV, Weber JBB, De Oliveira MG. Parent and caretaker knowledge about avulsion of permanent teeth. Dent Traumatol. 2009;25:203-8, doi: 10.1111/j.1600-9657.2008.00620.x

24. Pacheco LF, Filho PFG, Letra A, Menezes R, Villoria GEM, Ferreira SM. Evaluation of the knowledge of the treatment of avulsions in elementary school teachers in Rio de Janeiro, Brazil. Dent Traumatol. 2003;19:76-8, doi:10.1034/j.16009657.2003.00109.x

25. Côrtes MIS, Marcenes W, Sheiham A. Prevalence and correlates of traumatic injuries to the permanent teeth of schoolchildren aged 9-14 in Belo Horizonte. Dent Traumatol. 2001;7:22-6, doi:10.1034/j.1600-9657.2001.170105.x

26. Schwartz-Arad D, Levin L, Ashkenazi M. Treatment options of untreatable traumatized anterior maxillary teeth for future use of dental implantation. Implant Dent. 2004;13:120-8. doi: 10.1097/01.ID.0000116367.53563.19

27. Boyd DH, Kinirons MJ, Gregg TA. A prospective study of factors affecting survival of replanted permanent incisors in children. Int J Paediatr Dent. 2000;10:200-5, doi:10.1046/ j.1365-263x.2000.00192.x

28. Andersson L, Bodin I, Sorensen S. Progression of root resorption following replantation of human teeth after attended extraoral storage. Dent Traumatol. 1989;5:38-47, doi:10.1111/ j.1600-9657.1989.tb00335.x

29. Blakytny C, Surbuts C, Thomas A, Hunter ML. Avulsed permanent incisors: knowledge and attitudes of primary school teachers with regard to emergency management. Int J Paediatr Dent.2001;11:327-32. doi:10.1046/j.0960-7439.2001.00288.x 
30. Shamarao S, Jain J, Ajagannanavar SL, Haridas R, Tikare S, Kalappa AA. Knowledge and attitude regarding management of tooth avulsion injuries among school teachers in rural India. J Int Soc Prev Community Dent. 2014;4:44-8, doi: 10.4103/ 2231-0762.144599

31. Andersson L, Andreasen JO, Day P, Heithersay G, Trope M, DiAngelis AJ et al. International Association of Dental Traumatology guidelines for the management of traumatic dental injuries: 2. Avulsion of permanent teeth. Dent Traumatol. 2012;28:88-96, doi:10.1111/j.1600-9657.2012.01125.x
32. Al-Asfour A, Andersson L, Al-Jame Q. School teachers' knowledge of tooth avulsion and dental first aid before and after receiving information about avulsed teeth and replantation. Dent Traumatol. 2008;24:43-9. doi:10.1111/j.16009657.2006.00476.x

33. Arikan V, Sönmez H. Knowledge level of primary school teachers regarding traumatic dental injuries and their emergency management before and after receiving an informative leaflet. Dent Traumatol. 2012;28(2):101-7. doi:10.1111/j. 1600-9657.2011.01042.x

Sažetak

\section{POSTUPCI PRVE POMOĆI U HITNOM ZBRINJAVANJU OZLJEDA ZUBA - ZNANJE MEĐU UČITELJIMA U GRADU RIJECI, HRVATSKA}

\section{Bakarčić, S. Hrvatin, M. Maroević i N. Ivančić Jokić}

Cilj ovoga istraživanja bio je procijeniti znanje i stav prema hitnom zbrinjavanju ozljede zuba među učiteljima osnovnih škola u gradu Rijeci, Hrvatska. Ukupno 144 učitelja ispunilo je upitnik podijeljen u 4 dijela, koji se odnosio na opće podatke, vrstu i odgovornost radnog mjesta, stečeno znanje o dentalnim traumama i želju za daljnjom izobrazbom o tom pitanju. Gotovo polovica ispitanika $(47,2 \%)$ susrela se s barem jednom ozljedom zuba tijekom svog radnog staža. U trenutku nezgode $54,1 \%$ ispitanika pozvalo je prvo roditelje djeteta, a samo $11,1 \%$ učitelja kontaktiralo je doktora dentalne medicine. Većina $(81,9 \%)$ ispitanika nije nikada čula za termin avulsio dentis. U slučaju potpunog izbijanja zuba $17,3 \%$ učitelja primjereno bi zbrinulo zub, dok $14 \%$ njih ne bi ni dotakli zub. U vezi transporta izbijenog zuba ili slomljenog fragmenta samo $2 \%$ ispitanika odgovorilo je točno. Većina ispitanika (87,5\%) nisu nikad prošli nikakvu izobrazbu o ozljedama zuba, ali su izrazili želju za izobrazbom putem predavanja $(53,4 \%)$, tečajeva o hitnim postupcima $(15,2 \%)$ i letaka $(9,7 \%)$. Planiranje izobrazbe učitelja o dentalnim ozljedama putem tečajeva trajnog usavršavanja predlaže se kao dio njihovog cjeloživotnog obrazovanja.

Ključne riječi: Zub, ozljede; Zub, avulzija; Škole; Dijete; Adolescent; Mlada osoba; Zdravstveno znanje, stavovi, primjena; Poučavanje; Hitno zbrinjavanje - psihologija; Hrvatska 